Article

\title{
Here to Stay: The Evolution of Sexual and Reproductive Health and Rights in International Human Rights Law
}

\author{
Lucía Berro Pizzarossa ${ }^{(1)}$ \\ Department of Transboundary Legal Studies, University of Groningen, 9712EA Groningen, The Netherlands; \\ lberropizzarossa@gmail.com
}

Received: 8 May 2018; Accepted: 3 August 2018; Published: 7 August 2018

check for updates

\begin{abstract}
Sexual and reproductive health and rights have increasingly been recognized in the international arena, but their evolution and the definition of their scope and content have not been received without controversy. From population control to human rights, from demographers' competence to governmental prerogative, from couples' rights to universal rights, this article will present an overview of the evolution of sexual and reproductive rights in the international arena. The development of these rights cannot be read in isolation but must be analyzed together with the broader landscape that hosts social and political movements, ideologies, religions, and revolutions. Understanding sexual and reproductive health and rights as historical creations, rather than timeless givens, enables us to devise historically informed instruments and policies that are more likely to succeed. This article contributes to the scholarly literature by providing an overview of past trends and of the conditions under which they occurred. Retracing the history of these rights enables us to clarify the scope of the state's obligations to realize the right to sexual and reproductive health, to improve monitoring opportunities, and to ensure accountability for violations. This article explores these (and forthcoming) developments contributing to identify the existing obligations, the relevant actors, and the challenges that lie ahead.
\end{abstract}

Keywords: international human rights law; abortion; sexual and reproductive rights; family planning; right to health; reproductive health; reproductive rights; women's rights; gender

\section{Introduction}

While sexual and reproductive health and rights (SRHR) are increasingly recognized in the international arena, this evolution has not come without controversy. The development of these rights cannot be read in isolation but needs to be analyzed as part of the wider social and political movements, ideologies, and religions (Finkle and McIntosh 2002). The aim of this article is to retrace the historical evolution of SRHR and to contribute to the understanding of SRHR as historical creations rather than timeless givens (Orford 2012). We have better chances of realizing SRHR if we have a clear understanding of past trends, of their evolution, and of the conditions under which the changes occurred.

Taking these considerations as points of departure, this article will show the historical evolution of embedding SRHR in international human rights law. Four phases can be identified. The turning points are marked by the 1994 International Conference on Population and Development (ICPD), a fragmentation period marked by the United Nations' development agenda and the adoption of General Comment 22 on the Right to sexual and reproductive health by the Committee on Economic, Social, and Cultural rights in 2016 (CESCR). 
The structure of this article follows these four phases. Section 2 shows how SRHR were introduced as a concern related to population growth rather than a human rights issue. In Section 3, the paradigm shift brought by the ICPD will be discussed and two elements will be highlighted: consensus and compromise. Section 4 will focus on what Agarwal and Ray (Agarwal and Ray 2007) called the post-ICPD fragmentation phase. It will focus on the UN development agenda and its impact on SRHR. Finally, the work of the ICESCR in defining the scope and content of the right to sexual and reproductive health will be discussed.

This piece focuses on the shifts in thinking about SRHR from an international human rights law perspective-going from an interest in population control through family planning to a much wider approach, encompassing not only fertility control but also safe sex and pregnancy free from coercion, discrimination, and violence-and the political and social circumstances that hosted these shifts. The limitations of this piece refer to the focus and categorization of the evolution in paradigm shifts. This paper focuses on the context that has hosted the development of the key legal documents that have marked the evolution of SRHR. These key documents are understood to be the most authoritative sources of obligations regarding the realization of SRHR.

This paper does not engage with the developments of SRHR in the context of the Universal Periodic Review or national or regional forums nor does it engage with the review meetings of the programs of action adopted in Cairo and Beijing. The division of this paper into its phases responds to the abovementioned paradigms. The information is presented in this manner for clarity, intending to showcase the key dominant ideas that inspired the key legal developments. This paper does not follow a linear account and does acknowledge that the discussed paradigms coexist(ed).

\section{The Population Control Paradigm: From the 1954 Population Conference to the 1994 International Conference on Population and Development}

This section discusses the first stages in the development of SRHR until 1994. In this period the foundations for the later development of SRHR were introduced. The legal developments discussed here illustrate the dominant ideas of the population control paradigm.

\subsection{First Population Conferences: SRHR as the Domain of Demographers}

The United Nations (UN) brought the issue of population growth into the international agenda by convening the World Population Conference in 1954 in Rome and again in 1965 in Belgrade. The purpose of these conferences was to discuss the topic in general terms-not policy-and the participants were invited in their own independent capacities as demographers or population experts (Finkle and McIntosh 2002). Issues of population growth and control were not conceptualized in terms of human rights but as belonging to the domain of demographers.

By the time of the Belgrade conference (1965), there was a growing body of alarmist literature related to population growth. ${ }^{1}$ The prevailing ideas at the time- which permeated the legal field-were that "[t]he world population is growing at an accelerating rate" and that the most threatening consequence of this was the "danger of mass starvation" (Kellogg 1970). As a result, some governments considered population growth to be a security threat and began to perceive the need for population control.

Many governments supported family-planning programs to reduce their birth rate and slow population growth. These programs were grounded on the neo-Malthusian belief that claims that population growth is the main cause of poverty and an obstacle to development, because the more people there are in a given area, the fewer resources are available to support or develop everyone, (Ashford 2001). This belief prompted a series of coercive practices, and there

1 The first paragraph of Ehrlich's work reads as follows: "The battle to feed all of humanity is over .... At this late date nothing can prevent a substantial increase in the world death rate ..." (Ehrlich 1968). 
are extensive accounts of material incentives being offered to impoverished populations with the goal of capping population growth. Examples of these practices include women being forced to undergo abortions and social pressure being applied to monitor and control fertility (Zeidenstein 2009; Garcia-Moreno and Claro 1994).

In 1968, UN member states gathered in Teheran at the International Conference on Human Rights and adopted a resolution marking the first moment in which population control was explicitly linked to the advancement of human rights. The states participating in the conference believed that slowing the rate of population growth would offer "greater opportunities for the enjoyment of human rights and the improvement of living conditions" for each person. The Proclamation of Tehran reads " $t \mathrm{t}]$ he present rate of population growth in some areas of the world hampers the struggle against hunger and poverty [...] thereby impairing full realization of human rights" (United Nations Population Division 1968).

The dominant idea of this paradigm is that population growth represents a "problem" - an obstacle to the enjoyment of human rights-and it consequently triggered and justified a wide array of measures that dealt with the issue on those terms. The language of human rights entered the discussion on population control for the first time with the last instrument discussed (the Proclamation of Teheran). However, it did so in a very embryonic manner and was somehow co-opted by the "population control" paradigm, as the assertion that reducing population would enhance the chances of realizing human rights coexisted, somehow, with coercive and discriminatory practices.

\subsection{The Bucharest Population Conference and Beyond: A New Model Arises}

By 1970, influenced by the abovementioned narrative of governmental intervention for demographic control, the population conferences would no longer be "dominated by demographers". State representatives became the key actors in this arena with the active participation of civil society (Finkle and McIntosh 2002).

The Bucharest World Conference on Population (1974) brought to light a slightly different approach. This was the first global conference in which high-ranking government officials gathered to tackle the highly sensitive issue of population growth and its relationship to development. $^{2}$ A Plan of Action was adopted by consensus by 137 UN member states after hard negotiations. A group of countries challenged the abovementioned neo-Malthusian view, arguing that the "population problem" was a consequence and not a cause of underdevelopment and that the crux of the problem was not scarcity of resources but rather their distribution (UN Department of Economic and Social Affairs 2017). This conference hosted a greater involvement of less developed countries in the discussions on population growth and development than the previous ones and made an unequivocal move towards the centrality of human rights for these issues.

The World Population Plan of Action (WPPA) adopted at this conference introduced three major changes. Firstly, the WPPA clearly states that population policies should be consistent with human rights and demands that States "[r]espect and ensure, regardless of their over-all demographic goals, the rights of persons to determine, in a free, informed and responsible manner, the number and spacing of their children" (United Nations Population Division 1974a). This wording indicates that the right to decide freely and responsibly on the number and spacing of children and overrides governmental interests in population control. The WPPA also indicates that people should have access to the means to exercise these rights, a phrase that could be interpreted to cover a range of social and economic rights.

Secondly, it introduced the following wording: "[a]ll couples and individuals [italics added] have the basic right to decide freely and responsibly the number and spacing of their children"

2 The Population Division of the UN and the International Union for the Scientific Study of Population organized two previous population conferences (Rome (1954) and Belgrade (1965)), but these were meetings of experts in demography and related disciplines and not meetings of representatives of governments. 
(United Nations Population Division 1974a). This provision represents a strategic win for the human rights narrative. The phrasing "couples and individuals" was not in the original draft presented to the Bucharest conference, but the working group inserted it as a new principle. While many delegations were in favor of incorporating the term "individuals", several others expressed reservations as this choice of words may imply the availability and provision of contraceptives to the unmarried (United Nations Population Division 1974b). The matter was put to vote, and with 48 votes in favor (41 against and 6 abstentions), the formula "couples and individuals" was approved. This wording has withstood the test of time, and all later efforts to change or revise it have failed.

Thirdly, the WPPA emphasized the importance of the role of women and the interconnection of this role with population policies. According to this document, the "[e]qual status of men and women in the family and in society improves the overall quality of life" and should be fully realized in family planning, and the "[i]mprovement of the status of women in the family and in society can contribute, where desired, to smaller family size, and the opportunity for women to plan births also improves their individual status" (United Nations Population Division 1974a).

Throughout the 1970s and particularly after the Bucharest conference (1974), feminist criticisms of fertility control policies matured, and at the 1975 International Women's Year Conference in Mexico, several women's rights organizations denounced coercive practices in contraceptive research and practices and based the right to reproductive choice on a notion of bodily integrity and control (Correa and Reichmann 1994).

In 1984, Mexico City hosted the second International Conference on Population, in which the UN member states adopted the Recommendations for the Further Implementation of the WPPA. At this conference, the states confirmed the importance of human rights in the "population control" field but were faced with controversy sparked by the topics of abortion and the uses of coercive practices in the achievement of demographic goals.

On the one hand, the wording of the Recommendation for Further Implementations of the WPPA undoubtedly reflects a human-rights centered approach. Recommendation 30 urges states not only to ensure that all couples and individuals have the right to determine the number and spacing of their children freely and responsibly, but also that they receive the information, education, and means to do so. Moreover, Recommendation 31 demands that legislation and policies concerning the family and programs of incentives and disincentives should be neither coercive nor discriminatory and should be consistent with internationally recognized human rights (UN Second Conference on Population 1984).

On the other hand, two controversial issues were raised, which revealed the gap between the international commitments described above and the realistic political will of states to implement these rights.

Firstly, during this conference, the United States (US) and the Holy See stated their position regarding abortion, setting the international agenda for decades to come. These countries took a very strong line in the debates and stressed that abortion was not to be considered a method of family planning. The movement called "pro-life" had expanded, and the politics of reproduction of the US had spilled over to the international arena. During the conference, President Reagan announced the "Mexico City policy" (or "global gag rule"), specifying that federal funds for family planning were made available only to foreign nongovernmental organizations that agreed not to perform or promote abortion as a method of family planning (Solinger 2013). In spite of the concerns about "illegal abortions" raised by the Swedish delegate and the lobby to include a reference to "access to legal and safe abortions" in the text, there was no agreement on this point. In fact, Recommendation 18 (e)-the only provision to mention abortion-reads as follows: "[t]o take appropriate steps to help women avoid abortion, which in no case should be promoted as a method of family planning" (Grimes 1994; UN Second Conference on Population 1984).

Secondly, this conference (Mexico 1984) was also faced with the adoption of the Chinese birth control policies. Evidence of the coercive methods used by the Chinese government in its one-child policy had gained international attention, but the conference refused to publicly reject China's policies, 
in effect undermining the idea of family planning as a human right (Aguirre and Wolfgram 2001). This refusal indicated that the "basic human right of couples and individuals to decide freely and responsibly the number and spacing of their children" accepted in Bucharest was, therefore, circumscribed in its exercise in accordance with governmental demographic goals and in a manner that a given government considered "responsible".

With regards to the role of women, Paragraph 7 of the recommendations considered that "[i]n order to provide women with the freedom to participate fully in the life of society, it is equally necessary for men to share fully with women responsibilities in the areas of family planning, child-rearing and all other aspects of family life" (UN Second Conference on Population 1984). This statement is crucial, as it clearly links the ability of women to control their reproductive capacity with their full citizenship.

However, conditional international aid, limited family planning options, and coercive practices coexisted-and still do-with the obligation to realize SRHR. The outcome document of the conferences discussed above and the positions adopted regarding abortion or the use of coercive practices demonstrate that women's central role in reproduction was not an overriding concern in the population growth field.

Unsurprisingly, the population control paradigm faced extensive criticism. It was considered to (i) instrumentalize women's bodies to achieve population goals, and (ii) fail to address structural problems. Regarding the first point, scholars note that this approach was consistently oriented towards birth control rather than towards an integrated approach to reproductive health and rights and that its gender neutrality disregarded women's specific reproductive responsibility (Correa and Reichmann 1994). The women's movement argued that the way the population control approach defined the problem and the solution made women "factors" instead of "actors", or in Cook's words, "[w]omen benefited from the process, but were not at its centre. They were objects and not subjects" (Van Eerdewijk 2001; Cook et al. 2003). As to the second point, by focusing narrowly on women in poverty in the strategies to lower fertility, population policies were introduced to slow population growth without addressing any dimensions of social inequality (Petchesky 2003; De Barbieri 1993). Hartmann pointed out that "much needed reforms—-such as land redistribution, employment creation, the provision of mass education and health care, and the emancipation of women-were conveniently ignored", and this approach diverted attention and resources (Hartmann 2016).

As the population control paradigm was highly criticized by the women's movement, it triggered the active participation of women's rights organizations challenging these ideas in the subsequent conferences (Correa and Reichmann 1994).

\subsection{The Indivisibility of Human Rights}

The World Conference on Human Rights in Vienna (1993) endorsed the indivisibility of all human rights and urged States to guarantee the full and equal enjoyment by women of all human rights and the eradication of all forms of discrimination against women, both hidden and overt (UN World Conference on Human Rights 1993).

At this conference, women's rights activists and organizations argued that the UN Human Rights System did not promote and protect the dignity and human rights of women. On the particular topic of SRHR, the conference's Programme of Action recognized the importance of women's access to the highest standard of physical and mental health throughout their life span and reaffirmed women's rights to the widest range of family planning services (UN World Conference on Human Rights 1993).

\section{3. "Reproductive Rights Are Human Rights": The Human Rights Paradigm}

\subsection{International Conference on Population and Development in Cairo (1994): The Interplay of Already Recognized Human Rights}

The 1994 ICPD held in Cairo became a turning point in the international discussions on population. It was considered to have brought a major shift in the thinking and approach to population 
issues-from pure population control through family planning to a much wider field, encompassing not only fertility control, but also safe sex and pregnancy free from coercion, discrimination, and violence.

Roseman and Reichenbach point out that "[p]rior to the ICPD the international lexicon and national policies addressing population focused on the control of fertility, understood entirely as women's fertility" (Roseman and Laura 2009). This conference transformed the conversation, not only by delegitimizing top-down governmental efforts that ignored or violated women's human rights, but also by recognizing that policies on development in fact could not succeed without ensuring human rights. The ICPD's approach has been defined as horizontal, holistic, and human rights-based, contrary to the technical/vertical view of the population control paradigm.

\subsubsection{The ICPD Consensus}

The ICPD Programme of Action (ICPD PoA) established a consensus that governmental population policies must be built on the cornerstones of human rights. The conference adopted a series of definitions that are worth mentioning, not only because they serve as evidence of the paradigm shift above, but also because they build upon already recognized rights in order to construe the concepts of SRHR. This reference-that will be discussed in this section-brought all the legal developments on human rights to the field of population and development.

The term reproductive rights was to be formulated in a non-institutional framework, coined by the First International Meeting on Women and Health in Amsterdam (1984) and initially tied to the struggle for the rights to legal abortion and contraception in developed countries (Mattar 2008). The ICPD—following and expanding upon this approach—introduced the concept of reproductive rights to the international community and adopted a twofold definition. On the one hand, it conceptualized reproductive rights as "the basic rights of all couples and individuals to decide freely and responsibly the number, spacing and timing of their children and to have the information and means to do so, and the right to attain the highest standard of sexual and reproductive health". On the other hand, it stated that these rights "embrace certain human rights that are already recognized in national laws, international laws and international human rights documents and other consensus documents" (UN International Conference on Population and Development 1994a). With this statement, the PoA not only strengthens the definition of reproductive rights by linking it to human rights enshrined in binding instruments and by referring to the indivisibility of rights, but also managed to sideline the Holy See's concern that "new categories of rights" were being created (UN International Conference on Population and Development 1994b).

The ICPD PoA also offered a clear definition of the concept of reproductive health, developing the already existing definitions prepared by the World Health Organization (WHO), as well as a introducing a greater focus on the reproductive rights of individual men and women. The term reproductive health also emerged out of the women's health movement, which preceded the ICPD by at least two decades. The ICPD defines reproductive health as "a state of complete physical, mental and social well-being and not merely the absence of disease or infirmity, in all matters relating to the reproductive system and to its functions and processes. Reproductive health therefore implies that people are able to have a satisfying and safe sex life and that they have the capability to reproduce and the freedom to decide if, when and how often to do so" (UN International Conference on Population and Development 1994a).

At this point, organizations from all over the world had been galvanized by the coercive policies happening under the population control paradigm, gender-based discrimination, and restriction on abortion rights (Roseman and Laura 2009).

This concept of reproductive health was endorsed in the PoA as progressive and as a preferable alternative to the narrowly focused family planning programs, because it offered a comprehensive and integrated approach to health needs related to reproduction and put women at the center of the process. 


\subsubsection{The Holy See, the Unholy Alliance, and Its Role in the ICPD}

The introduction of the definitions of reproductive rights and reproductive health sparked a lot of controversy, especially from the Holy See. Pope John Paul II delivered a letter stating that "[i]n the face of the so-called culture of death, the family is the heart of the culture of life" (UN International Conference on Population and Development 1994c). His letter marked the start of one of the most heated campaigns of his term. On three occasions, he addressed the states participating in the conference, and several documents were presented stating the official position of the Holy See with regards to the draft of the Programme of Action. In these documents, the Holy See resisted the draft texts on abortion, sexual and reproductive rights of individuals, sterilization, and the use of condoms Although the Holy See only has an observer status at the UN, it considers itself to be the moral representative of all Catholics, and it has played a very active role in these discussions. ${ }^{3}$ It should certainly not be underestimated that the Holy See continues to exercise considerable influence on these discussions and that its opinions and alliances have had and continue to have a long-lasting impact.

The Holy See stated that the phrase "couples and individuals" as used in the ICPD PoA refer to married couples and the individual man and woman who constitute the couple. According to the Holy See, no sexual and reproductive rights should be recognized and guaranteed to those outside of the traditional, heterosexual monogamous marriage. The Holy See's statement at the ICPD stated that "[t]he Holy See strongly rejects any attempts to weaken the family or to propose a radical redefining of its structure, such as assigning the status of family to other life-style forms" (UN International Conference on Population and Development 1994b). ${ }^{4}$

These ideas were also initially supported by the Islamic front. Prior to the ICPD, officials from the Holy See organized a meeting with representatives from the World Muslim League and other Islamic groups. In a joint statement, they criticized the "extreme individualism" and "moral decadence" of the ICPD. However, this pact broke up during the conference, because while their interests overlapped, they also differed. The Holy See was most concerned about abortion, while the Islamic states focused on blocking access to family planning services for adolescents and to oppose sexual health and sexual rights (Zimmerman 2015).

The literature has called this an "unholy alliance", as religious entities came together to fight the language of SRHR and mostly the very notion of gender equality (Hulme 2010; Berer 2001). The underlying idea behind this opposition was a "negative and decidedly discriminatory vision of women and the exercise of sexuality", observed Mattar (Mattar 2008). These types of alliances have been criticized, as they pose a threat to the universality of human rights and represent the political use of religion, culture, and tradition to deprive women, unmarried individuals, sexual minorities, and others of their SRHR. As we will see, this was not the only time that conservative religious entities have opposed the development of SRHR.

Ultimately, the final version of the ICPD PoA was partially endorsed by the Holy See, which was the first time that it had given even qualified support to a such a document on the topic of population and development, having previously refused to endorse the documents produced at the 1974 and 1984 UN conferences in Bucharest and Mexico City, respectively (Beattie 2014).

3 Various scholars, nongovernmental organizations (NGOs), and official delegations considered that its position at the UN should be revised as it does not behave as a state but as a religion, thereby having a position that other religions do not enjoy. See for example Kissling and Shannon (1996).

4 The Holy See's Statement expressing its reservations to the ICPD PoA reads as follow "Regarding the terms 'sexual health' and 'sexual rights', and 'reproductive health' and 'reproductive rights', the Holy See considers these terms as applying to a holistic concept of health, which embrace, each in their own way, the person in the entirety of his or her personality, mind and body, and which foster the achievement of personal maturity in sexuality and in the mutual love and decision-making that characterize the conjugal relationship in accordance with moral norms" (UN International Conference on Population and Development 1994a). 


\subsubsection{The Role of the Already Recognized Human Rights in the Elaboration of SRHR}

The ICPD PoA builds upon previously enshrined and widely accepted human rights, articulating sexual and reproductive rights as already existing human rights that are now specifically applied to experiences related to reproduction (Roseman and Laura 2009). It stated that reproductive rights embrace certain human rights that are "already recognized" in national laws, international laws, and international human rights documents and other consensus documents.

These already recognized rights, which underpin the definition of SRHR, refer directly to the UN core human rights treaties and have both grounded and inspired the work of the UN treaty-monitoring bodies when dealing with violations of SRHR. This section will show how the different monitoring bodies of the UN have used the "already recognized" human rights codified by these treaties to monitor states' actions towards the realization of SRHR and to assess their violation. ${ }^{5}$

As mentioned above the right to health-enshrined in Article 12 of the International Covenant on Economic, Social, and Cultural Rights-has played an important role in defining the scope and content of SRHR. In its General Comment 14 on the Right to Health, the CESCR states that reproductive health is an integral part of the right to health, meaning that women and men have the freedom to decide if and when to reproduce, the right to be informed and to have access to safe, effective, affordable, and acceptable methods of family planning of their choice, and the right of access to appropriate healthcare services. Moreover, General Comment 14 frames the right to information on sexual and reproductive health as an essential component of the right to health. (UN Committee on Economic, Social and Cultural Rights 2000).

Furthermore, the right to life-recognized in Article 6.1 of the International Covenant on Civil and Political Rights-has underpinned the UN monitoring bodies' argument that the consequences of unsafe abortions-pandemic preventable maternal deaths-interfere with the right to life of the mother. For example, the Human Rights Committee (HRC) called upon states to "help women prevent unwanted pregnancies, and to ensure that they do not have to undergo life-threatening clandestine abortions" (UN Human Rights Committee 2000). The Committee on the Elimination of Discrimination against Women (CCEDAW) has also given considerable attention to the issue of maternal mortality due to unsafe abortion in numerous sets of concluding observations and has explicitly framed the issue as a violation of women's right to life (UN Committee on the Elimination of Discrimination against Women (CEDAW) 1998).

The rights to equality and non-discrimination have also been pivotal, as women bear the health consequences of childbearing, and in most cases, childcare as well. It is widely believed that human rights violations against women, and thus women's vulnerability to disease, disability, and premature death, are often perpetuated by deep-rooted patterns of gender discrimination. The Convention on the Elimination of All Forms of Discrimination against Women is the only human rights treaty, which affirms the reproductive rights of women. The interplay of Articles 12 (the right to be free from discrimination in the field of healthcare) and 16 (the right to be free from discrimination in all matters relating to marriage and family relations) is pivotal for the recognition of SRHR for women. In its General Recommendation No. 24 on women and health, the CCEDAW has recognized the inextricable link between women's right to health during pregnancy and childbirth and their other human rights (UN Committee on the Elimination of Discrimination against Women (CEDAW) 1999). The committee explained that the provision of reproductive health services is essential to women's equality, and that "it is discriminatory for a State Party to refuse to provide legally for the performance of certain reproductive health services for women." (UN Committee on the Elimination of Discrimination against Women (CEDAW) 1998).

The adoption of the International Covenant on Civil and Political Rights (ICCPR), the International Covenant on Economic, Social, and Cultural Rights (ICESCR), and the Convention on the Elimination

5 For a more extensive analysis, see United Nations Population Fund et al. (2014), Center for Reproductive Rights (2009). 
of all forms of Discrimination against Women (CEDAW) provided a strong legal framework for the development of SRHR. The UN human rights treaty bodies have a key role in establishing the normative content of SRHR and in giving concrete meaning to these rights and state obligations. As the following sections will show, over time, these bodies have assumed a bolder role in the monitoring of state performance, by defining the scope and obligations of states regarding the realization of SRHR in general comments and reports and by monitoring states' work towards their realization through recommendations stemming from periodic reporting and from individual communications.

\subsection{The Cairo Compromise}

While the ICPD indeed represented a consensus, it also represented an important compromise on a topic of major importance: the topic of abortion. This matter sparked a heated debate and the final document is far removed from what was initially envisaged to be, a positive outcome of the conference. Berer notes that the ICPD PoA distanced itself from the evidence-based approach it took with regards to other topics and treated abortion not as a means of fertility regulation or as a legitimate reproductive health service but as something that must be prevented (Berer 2009). The following sentence-first formulated in 1984 as per request of the Reagan Administration-evidences the ICPD PoAs overall approach to abortion: "In no case should abortion be promoted as a method of family planning" (UN International Conference on Population and Development 1994a).

Although the ICPD fell short of demanding universal safe and legal abortions, it asked state members to confront the public health consequences of unsafe abortions and to ensure that in circumstances where abortion is not against the law, such abortion should be safe. This provision was strongly criticized by the Holy See, who responded that it "rejects any recognition of a right to abortion through policies aimed at creating new categories of personal rights ... no nation should be forced to change or violate its own laws that prohibit or regulate abortion practices" (UN Commission of the UNDP 1999).

The compromise had a negative impact on the advancement of a comprehensive SRHR agenda in the international arena. The issue of abortion has been largely absent in the discussion of the political bodies and the ICPD compromise "brood[ed] omnipresently over all sessions" (Miller and Roseman 2011). In the decades to follow, it was noted that even leading advocates on SRHR, such as Paul Hunt, did not push beyond the 1994 ICPD agreement in their demands.

\subsection{The Fourth World Conference on Women (1995), the Beijing Declaration, and the Platform for Action: Reinforcing Decisional Autonomy and Incorporating Sexual Rights}

In 1995, the Beijing Declaration and Platform for Action (PfA) recognized that "[ $t$ ]he right of all women to control all aspects of their health, in particular their fertility, is basic to their empowerment" (UN Fourth World Conference on Women 1995). The conference reaffirmed the goals and standards on SRHR set out in the ICPD but elaborated on women's interests, stating that "[e]qual relationships between women and men in matters of sexual relations and reproduction, including full respect for the integrity of the person, require mutual respect, consent and shared responsibility for sexual behaviour and its consequences". Furthermore, the Beijing PfA also directly called upon UN member states to review their laws, especially those laws which still imposed punitive measures upon women who "have undergone illegal abortions".

In Beijing, the Holy See continued to endeavor to draw a distinction between SRHR and what they considered to be the authentic advancement of women's rights. The Holy See's delegates stated that such advancement could only happen through the recognition of the deep "fundamental anthropological truths about man and woman" and that the SRHR movement is "largely individualistic" (Coates et al. 2014). The abovementioned unholy alliances were also present in this conference, and they targeted the way in which the Beijing Platform for Action dealt with women's autonomy in relation to sexuality and reproductive function (Steans and Ahmadi 2005). 


\section{The Post-ICPD Fragmentation Era}

The momentum gained in 1994 was followed by an era of fragmentation. Various authors (Garita 2014) describe the ICPD as the height of the SRHR momentum and point to how the discussion became dispersed, leaving the topic to be addressed in a fragmented manner-limited for example to quantifiable goals or circumscribed to sexual and reproductive health but not rights.

This era is marked by fragmented developments happening in diverse forums such as (a) the recognition of the crucial role of SRHR in achieving gender equality (see Sustainable Development Goals, SDGs) and their inextricable link with sustainable development, (b) the adoption of measurable markers regarding SRHR (and the somewhat reduction of SRHR to quantifiable goals), and (c) the work of the treaty-monitoring bodies' elaboration on the right to sexual and reproductive health (no elaboration in terms of sexual and reproductive rights) and potentially the right to life (with important consequences regarding abortion).

\subsection{The UN Development Agenda and SRHR: The Millennium Development Goals and the Sustainable Development Goals}

In 2000, during the discussion of the Millennium Development Goals (MDGs), political opponents of SRHR managed to sideline the importance of the realization of SRHR for the achievement of the goals (directly or indirectly).

Target 5A was the initial target of the MDG health goal, and its objective was limited to the reduction of maternal mortality by three quarters. Target $5 \mathrm{~B}$, in which the objective was universal access to reproductive health, was only added in 2005-five years later, and was not implemented until seven years after that-in the face of substantial political opposition. ${ }^{6}$ The literature points at a significant political backlash from several forces at the global level, ranging from realignments in the G-77 to pressures from the Holy See, conservative Islamic states, and evangelical Christians in the United States (Yamin 2013). This opposition blocked, for example, the introduction of the term reproductive health (instead of maternal health), preventing the MDGs from adopting a more comprehensive and human rights-compliant framework.

As the MDGs were originally completely silent on the role and importance of SRHR in improving health (especially, maternal and new born health) and in promoting economic and gender empowerment, it is no surprise that little was achieved (Galati 2015). The MDGs have been harshly criticized for failing to address women's rights as a fundamental determinant of women's health and for deliberately focusing on maternal health rather than sexuality and reproduction. In terms of funding, the absence of SRHR from the description of the goals signaled to donors and countries that they should focus their attentions elsewhere. Again, such a narrow approach reducing SRHR to "maternal health" impacted the effective achievement of the goal and the potential contribution to the achievement of other goals such as gender equality (Yamin and Boulanger 2013).

The most recently adopted 2030 Agenda for Sustainable Development (2015) does include goals and targets to be achieved in the area of SRHR and contains explicit references to human rights instruments such as the ICPD or the Beijing Platform. ${ }^{7}$ In a broader development perspective, SRHR is also among the key objectives of the Sustainable Development Goals (SDGs), and direct references to human rights treaties on SRHR are found in the targets themselves. Under SDG 3, governments agreed that by 2030 they would "ensure universal access to sexual and reproductive health care services, including for family planning, information and education, and the integration of reproductive health into national strategies and programmes" (Target 3.7). Under SDG 5, they also agreed to "ensure

6 Target 5B was belatedly added to the Millenium Development Goals in 2005, and the indicators for this target were officially established in 2007. See United National General Assembly (2005).

7 United Nations, Transforming Our World: The 2030 Agenda for Sustainable Development, adopted by the UN General Assembly in September 2015, contains Goal 3 (Ensure healthy lives and promote wellbeing for all at all ages) and Goal 5 (Achieve gender equality and empower all women and girls). 
universal access to sexual and reproductive health and reproductive rights as agreed in accordance with the Programme of Action of the ICPD and the Beijing Platform for Action and the outcome documents of their review conferences" (Target 5.6). The Global Strategy for Women's, Children's, and Adolescents' Health (2016-2030) has as a key objective to "expand enabling environment" where the right to health and wellbeing can be achieved, specifically by removing barriers to the enjoyment of rights and by promoting gender equality (Bustreo et al. 2013). Unlike the MDGs, the SDGs reframe women's health around SRHR and adopt a life-cycle approach that is not restricted to maternal health and exists independently from reproductive capacity.

\subsection{Defining State Obligations: General Comment 22 on the Right to Sexual and Reproductive Health and the} Draft General Comment 33 on the Right to Life

In 2016, the discussions on SRHR witnessed a break-through with the adoption of General Comment 22 on the right to sexual and reproductive health (GC 22) by the CESCR, the treaty-monitoring body of the ICESCR. In response to the continuing grave violations in practice and adopting a clear human rights-based approach to matters of sexuality and reproduction, the CESCR adopted GC 22, extensively addressing states' legal obligations to realize the right to sexual and reproductive health (UN Committee on Economic, Social and Cultural Rights 2016).

As shown in the previous sections, the notion of SRHR came from a highly politicized context, and the definitions vary depending on whether they are used by a health activist, a population scientist, or a religious conservative (Basu 2009). The CESCR recognizes this ambiguity as a hurdle for the realization of these rights and identifies two key bases to develop the GC: firstly, the developments achieved in particular by the ICPD and the Beijing conference, and secondly, the instrumental work done by the UN monitoring mechanisms that have slowly but steadily contributed to the definition of the scope and content of the states' obligations regarding SRHR.

GC 22 contains four key components: it (a) adopts a life-cycle approach, therefore not reducing SRHR to "maternal health", (b) recognizes that SRHR are both indivisible from and interdependent with other human rights, (c) rejects all forms of coercive practices in SRHR, and (d) recognizes the particularly gendered experiences of SRHR, stating that due to women's reproductive capacities, the realization of women's right to sexual and reproductive health is essential to the realization of the full range of their human rights.

GC 22 affirms that the right to sexual and reproductive health is an integral part of the right to health that has enjoyed longstanding recognition based on preexisting international human rights instruments. ${ }^{8}$

The legal obligations to respect, protect, and fulfill the right to sexual and reproductive health offered/identified in General Comment 22 provide clear guidance to state parties. According to GC 22, the duty to respect requires states to refrain from interfering with individuals' right to exercise their sexual or reproductive health. Examples of such interference include limiting or denying access to health services and information, such as laws or practices that criminalize abortion or exclude certain health services from publicly or donor-funded programs.

Under the obligation to protect, states must protect individuals' right to sexual and reproductive health from interference by third parties. This includes protecting against private health clinics or insurance or pharmaceutical companies that impose practical or procedural barriers to health services.

8 The General Comment refers to General Comment 14: the right to the highest attainable standard of health (Art. 12 of the Covenant) (2000) § 2, 8, 11, 16, 21, 23, 34 , and 36. GC 22 uses the following documents as examples: Convention on the Elimination of All Forms of Discrimination against Women (1979), Article 12; Convention on the Rights of the Child (1989), Articles 17, 23-25, and 27; and Convention on the Rights of Persons with Disabilities (2006), Articles 23 and 25; see also the Committee on the Elimination of Discrimination Against Women (CEDAW) General Recommendation No. 24: Women and Health (1999), paras 11,14, 18, 23, 26, 29, 31(b); and the Committee on the Rights of the Child (CRC), General Comment 15: the right of the child to the enjoyment of the highest attainable standard of health (2013). 
States must introduce laws and policies that prohibit third parties from acting in a way that undermines the enjoyment of the right to sexual and reproductive health.

The obligation to fulfill mandates states "to adopt appropriate legislative, administrative, budgetary, judicial, promotional and other measures to ensure the full realization of the right to sexual and reproductive health". States must take steps to ensure universal access to sexual and reproductive healthcare, including emergency contraception and access to safe abortion services. States are required to provide comprehensive education about sexual and reproductive health for all and to take measures to eradicate social barriers that prevent individuals from exercising their right to sexual and reproductive health.

Although the General Comment falls short on an elaboration of sexual health or sexual rights, it definitely constitutes a step forward in the clarification of the international obligations of the states. Hopefully this development will ground better legal frameworks and policies and ensure accountability for the violations suffered worldwide.

UN Human Rights Committee's (HRC) Upcoming General Comment on the Right to Life

In July 2015, the treaty-monitoring body of the ICCPR, on the occasion of its 114th session, namely the UN HRC, held a half day of general discussion in preparation for a General Comment on Article 6 (Right to Life) of the ICCPR (Draft General Comment 33 (Draft GC 33)). In the leadup to the discussion, the HRC invited interested stakeholders to participate and provide written information, receiving 116 submissions.

As was outlined above, the right to life has been at the core of the debate on SRHR, particularly with regards to abortion. The tension between the different views on abortion has been the object of extensive analysis, but it has not been explicitly decided in any binding universal instruments (UN Human Rights Committee 2015).

The position adopted in the drafts of this upcoming General Comment goes in line with the extensive elaboration made by the UN monitoring bodies on the matter of abortion and the right to life and effectively means that any legal restrictions on the ability of women to seek an abortion must not jeopardize their lives or subject them to severe physical or mental pain or suffering. However, it is important to remain vigilant, because the first draft had considerably more explicit wording.

In terms of the regulation of terminations of pregnancy, both drafts decidedly considered that states parties must provide safe access to abortion to protect the life and health of pregnant women and in situations in which carrying a pregnancy to term would cause the woman substantial pain or suffering, most notably where the pregnancy is the result of rape or incest or when the fetus suffers from fatal impairment. States parties may not regulate pregnancy or abortion in a manner that runs contrary to their duty to ensure that women do not have to undertake unsafe abortions.

Upon finalizing this article, the adoption of this Draft GC 33 and the extent of its final content were still uncertain.

\section{Perspectives for the Future?: Final Remarks}

Cook states that "[n]o society, no religion, no culture and no system of national law has been neutral about issues of human reproduction" (Cook et al. 2003). Indeed, because SRHR entail moral, religious, ethical, and philosophical questions, the history of their recognition has not been without controversy. This article has discussed how SRHR have evolved in the international arena, paying specific attention to the different approaches, the different resulting policies and the relevant driving forces. South African Justice Albie Sachs stated that "a page of history is worth a volume of logic" (Southern African Legal Information Institute 1998). Indeed, through the analysis of the historical evolution of SRHR, this article has demonstrated that legal progress is neither linear nor understandable without careful consideration of the grander landscape in which it was hosted. This analysis is twofold, referring both to the past and to the future of sexual and reproductive rights in the international human rights law arena. 
On the one hand, this article has shown that SRHR cannot be fully understood without references to their historical evolution. The first stage in the evolution-discussed in Section 2-shows how the discussion surrounding SRHR stemmed from states' desire to curb population growth. This approach-in addition to the scarce elaboration on human rights-legitimized the use of coercive and discriminatory practices that lead to the instrumentalization of women's bodies. Section 3 shows how the ICPD marked a change in paradigm and led to a stronger recognition of SRHR as human rights. The ICPD Conference represented the golden age of SRHR in which basic definitions were adopted and strong political commitments were made. This conference was followed by a period of stagnation and renewed opposition up until 2016. Since 1994, using the ICPD as a framework, UN agencies have been pushing states to adopt a human rights-based approach to all programs-especially those related to SRHR. Section 4 has shown the upsurge of the opposition to SRHR and its impact on the development agenda-limiting these rights to "maternal health". This approach resulted in little progress in the MDGs era, and the results of the SDGs are yet to be seen. GC 22 marks a breakthrough, affirming Orford's assertion that the past is constantly being retrieved and clarifying the scope and content of the states' obligation to realize the right to sexual and reproductive health (UN Population Fund (UNFPA) 2010; UN Office of the United Nations High Commissioner for Human Rights (OHCHR) 2006; UN Population Fund (UNFPA) 2005). As was shown above, GC 22 builds on the extensive work previously done by the CESCR - and other UN monitoring mechanisms-and draws upon the rich history of the previous international instruments. GC 22 decisively rejects reductionist and coercive approaches, recognizes the independence and indivisibility of human rights, and affirms that women's right to sexual and reproductive health is indispensable to their autonomy and their right to make meaningful decisions about their lives and health.

On the other hand, assessing the future requires us to address the many challenges that lie ahead and that have been present since the initial discussions: religious fundamentalism, conservative politics, increased funding constraints, and the uphill battle for gender justice. As demonstrated by this article, retracing the history of SRHR shows us that none of these challenges are new. A growing conservative opposition -in particular to abortion and sexual rights-the "unholy alliances", formed at the UN between diverse religious sectors, and funding conditionalities can be traced back to the first population conferences; the gaps in the realization of these rights are, in turn, reflective of this opposition.

Firstly, various rights that exist in the umbrella notion of SRHR -in particular sexual rights and abortion-still face strong opposition. Sexual rights are often conceptualized in negative terms and require much further elaboration; as noted by Corrêa, "it has become extremely difficult to even mention the word sex in broad intergovernmental negotiations" (Agarwal and Ray 2007). As for the topic of abortion, at both the international and national levels, there is increasingly little room for dialogue on all related issues (Yamin and Bergallo 2017).

Secondly, we are witnessing a "religious resurgence" that has created a greater platform for socially conservative views in global public policy (Haynes 2013). For example, the Holy See has maintained a constant conservative positions towards SRHR but has "modernized" its language by selectively appropriating accepted UN language to bolster its own arguments, becoming one of the most active actors in the discussions at the UN forums. ${ }^{9}$ This is not to say that the Holy See is the only opposing agent, quite on the contrary; as noted by NORAD "Catholics and Mormons; Christians and Muslims; Russian Orthodox and American fundamentalists find common ground on traditional values and against SRHR issues at the UN" (Norwegian Agency for Development Cooperation 2013). The Report of the Special Rapporteur in the field of cultural rights—released in 2017—emphasizes

9 The diplomatic engagement of the Holy See in debates concerning sexual and reproductive health rights has increased from an average of two (2.3) statements per year during the period of 2003-2009 to an average of nine (8.75) statements per year during 2010-2013. 
how religious fundamentalism rejects values of equality and the universality of human rights and, under the labels of "purity" and "modesty", aim to limit the enjoyment of women's human rights and restrict the sexual and reproductive rights of all (UN Human Rights Council 2017). Since the 1990s—but with a renewed strength — the term gender ideology has gained space in the SRHR arena. Gender ideology refers to the decoupling of sex and gender and to the critique of traditional gender roles. SRHR requires us to challenge gender norms by, among other things, decoupling sex and reproduction; this is seen as a threat to the traditional patriarchal family structure and is therefore still highly resisted. As noted by Garbagnoli, the term ideology of gender is "a controversial invention of the catholic conservative circles which aims to caricature and thus to delegitimize a field study" (Garbagnoli 2016). Those who oppose abortion rights, and SRHR more generally, have argued that recognizing such rights represents what the Holy See, for example, sees as "culture of death" (UN International Conference on Population and Development 1994c), construing sexual and reproductive health and rights as a fundamental threat to the traditional patriarchal family (Yamin and Bergallo 2017).

Thirdly, since the 1980s, the global gag rule has subjected substantial funding for SRHR to the volatility of the bipartisan politics of the US. Notably, President Trump's version of the global gag rule has expanded upon the restrictions to obtain US funds and has decided to defund the United Nations Population Fund. The subsequent losses in funding are estimated to be around US $\$ 9$ billion, resulting in potentially dramatic consequences (Yamin and Bergallo 2017).

This article has shown that it is the evolution of the interpretation of human rights and their increased sophistication and human rights activism - particularly in women's rights - that have given force to SRHR. Understanding SRHR as historical creations rather than timeless givens, enables us to devise historically informed policies that are more likely to succeed. The opposition has not seemed to become less zealous over time (Glasier et al. 2006), so human rights scholars, activists, and policymakers must remain vigilant of the challenges. An unwavering defense of the achievements attained so far should be the touchstone of the human rights response. SRHR are here to stay.

Funding: This research received no external funding.

Acknowledgments: The author would like to thank Brigit Toebes for her comments on an earlier version of this paper.

Conflicts of Interest: The author declares no conflict of interest.

\section{References}

Agarwal, Manmohan, and Amit Shovon Ray, eds. 2007. Globalization and the Millennium Development Goals: Negotiating the Challenge. New York: Berghahn Books.

Aguirre, Maria Sophia, and Ann Wolfgram. 2001. United Nations Policy and the Family: Redefining the Ties that Bind: A Study of History, Forces and Trends. BYU Journal Public Law 16: 113.

Ashford, Lori S. 2001. New Population Policies: Advancing Women's Health and Rights. Washington: Population Reference Bureau.

Basu, Alaka. 2009. Situating Reproductive Health within the Academy. In Reproductive Health and Human Rights: The Way Forward. Philadelphia: University of Pennsylvania Press, p. 182.

Beattie, Tina. 2014. Whose Rights, Which Rights?-The United Nations, the Vatican, Gender and Sexual and Reproductive Rights. The Heythrop Journal 55: 1080-90. [CrossRef]

Berer, Marge. 2001. Images, reproductive health and the collateral damage to women of fundamentalism and war. Reproductive Health Matters 9: 6-11. [CrossRef]

Berer, Marge. 2009. The Cairo "compromise" on abortion and its consequences for making abortion safe and legal. In Reproductive Health and Human Rights: The Way Forward. Philadelphia: University of Pennsylvania Press, pp. 152-63.

Bustreo, Flavia, Paul Hunt, and World Health Organization. 2013. Women's and Children's Health: Evidence of Impact of Human Rights. Geneva: World Health Organization. 
Center for Reproductive Rights. 2009. Twelve Human Rights Key to Reproductive Rights. New York: Center for Reproductive Rights.

Coates, Amy L., Peter S. Hill, Simon Rushton, and Julie Balen. 2014. The Holy See on sexual and reproductive health rights: Conservative in position, dynamic in response. Reproductive Health Matters 22: 114-24. [CrossRef]

Cook, Rebecca J., Bernard M. Dickens, and Mahmoud F. Fathalla. 2003. Reproductive Health and Human Rights: Integrating Medicine, Ethics, and Law. Wotton-under-Edge: Clarendon Press.

Correa, Sonia, and Rebecca Lynn Reichmann. 1994. Population and Reproductive Rights: Feminist Perspectives from the South. London: Zed Books.

De Barbieri, Teresita. 1993. Gender and population policies: Some reflection. Reproductive Health Matters 1: 85-92. [CrossRef]

Ehrlich, Paul R. 1968. The Population Bomb. Rivercity: Rivercity Press, p. 11.

Finkle, Jason L., and C. Alison McIntosh. 2002. United Nations Population Conferences: Shaping the Policy Agenda for the Twenty-first Century. Studies in Family Planning 33: 11-23. [CrossRef] [PubMed]

Galati, Alanna J. 2015. Onward to 2030: Sexual and reproductive health and rights in the context of the Sustainable Development Goals. Guttmacher Policy Review 18. Available online: https:/ /www.guttmacher.org/gpr/2015/ 10/ onward-2030-sexual-and-reproductive-health-and-rights-context-sustainable-development (accessed on 4 August 2018).

Garbagnoli, Sara. 2016. Against the Heresy of Immanence: Vatican's 'Gender' as a New Rhetorical Device against the Denaturalisation of the Sexual Order. Religion and Gender 6: 187-204. [CrossRef]

Garita, Alexandra. 2014. Moving toward Sexual and Reproductive Justice: A Transnational and Multigenerational Feminist Remix. In The Oxford Handbook of Transnational Feminist Movements. Edited by Rawwida Baksh and Wendy Harcourt. New York: Oxford University Press, Available online: http:/ / www.oxfordhandbooks.com/view/10.1093/oxfordhb/9780199943494.001.0001/oxfordhb9780199943494-e-029 (accessed on 4 August 2018).

Garcia-Moreno, Claudia, and Amparo Claro. 1994. Challenges from the women's health movement: Women's rights versus population control. In Population Policies Reconsidered: Health, Empowerment, and Rights. Boston: Harvard University Press, pp. 47-72.

Glasier, Anna, A. Metin Gülmezoglu, George P. Schmid, Claudia Garcia Moreno, and Paul F. Van Look. 2006. Sexual and reproductive health: A matter of life and death. The Lancet 368: 1595-607. [CrossRef]

Grimes, Seamus. 1994. The ideology of population control in the UN draft plan for Cairo. Population Research and Policy Review 13: 209-24.

Hartmann, Betsy. 2016. Reproductive Rights and Wrongs: The Global Politics of Population Control. Chicago: Haymarket Books.

Haynes, Jeffrey. 2013. Faith-Based Organisations at the United Nations. Fiesole: European University Institute.

Hulme, David. 2010. Reproductive Health and the Millennium Development Goals: Politics, Ethics, Evidence and an 'Unholy Alliance'. Manchester: Brooks World Poverty Institute, University of Manchester.

Kellogg, Alfr. 1970. Population Growth and International Law. Cornell International Law Journal 3: 93-100.

Kissling, Frederike, and Daryl Shannon. 1996. Church and state at the United Nations. A case of the emperors new clothes. Conscience 16: 11-12. [PubMed]

Mattar, Laura Davis. 2008. Legal recognition of sexual rights: A comparative analysis with reproductive rights. Sur Revista Internacional de Direitos Humanos 5: 60-83. [CrossRef]

Miller, Alice M., and Mindy J. Roseman. 2011. Sexual and reproductive rights at the United Nations: Frustration or fulfilment? Reproductive Health Matters 19: 102-18. [CrossRef]

Norwegian Agency for Development Cooperation. 2013. Lobbying for Faith and Family: A Study of Religious NGOs at the United Nations. Available online: https://www.oursplatform.org/wp-content/uploads/ lobbying-for-faith-and-family.pdf (accessed on 4 August 2018).

UN Office of the United Nations High Commissioner for Human Rights (OHCHR). 2006. Frequently Asked Questions on a Human Rights-Based Approach to Development Cooperation. Geneva: OHCHR.

Orford, Anne. 2012. In praise of description. Leiden Journal of International Law 25: 609-25. [CrossRef]

Petchesky, Rosalind Pollack. 2003. Global Prescriptions: Gendering Health and Human Rights. London: Zed Books. 
Roseman, Mindy, and Reichenbach Laura. 2009. Global reproductive health and rights: reflecting on ICPD. In Reproductive Health and Human Rights: The Way Forward. Edited by Laura Reichenbach and Mindy Roseman. Philadelphia: University of Pennsylvania Press, pp. 3-20.

Solinger, Rickie. 2013. Reproductive Politics. Oxford: Oxford University Press.

National Coalition for Gay and Lesbian Equality and Another v Minister of Justice and Others. Available online: http:/ / www.saflii.org/za/cases/ZACC/1998/15.html (accessed on 6 August 2018).

Steans, Jill, and Vafa Ahmadi. 2005. Negotiating the politics of gender and rights: Some reflections on the status of women's human rights at 'Beijing Plus Ten'. Global Society 19: 227-45. [CrossRef]

UN Commission of the UNDP. 1999. Statement of Vescovo James T. Hugh at the 32nd Session of the Commission. Available online: http://www.vatican.va/roman_curia/secretariat_state/documents/rc_segst_doc_19990327_onu-population-develop_en.html (accessed on 23 December 2017).

UN Committee on Economic, Social and Cultural Rights. 2000. General Comment No. 14: The Right to the Highest Attainable Standard of Health. Geneva: UN Committee on Economic, Social and Cultural Rights.

UN Committee on Economic, Social and Cultural Rights. 2016. General Comment No. 22: Right to sexual and reproductive health (Art. 12 of the Covenant). E/C.12/GC/22. Geneva: UN Committee on Economic, Social and Cultural Rights.

UN Committee on the Elimination of Discrimination against Women (CEDAW). 1999. General Recommendation No. 24: Article 12 of the Convention (Women and Health). A/54/38/Rev.1. New York: CEDAW.

UN Committee on the Elimination of Discrimination against Women (CEDAW). 1998. Report of the Committee on the Elimination of Discrimination against Women (CEDAW) 18th and 19th Session. New York: CEDAW.

UN Department of Economic and Social Affairs. 2017. Conferences on Population. Available online: http:/ / www. un.org/en/development/desa/population/events/conference/index.shtml (accessed on 23 August 2017).

UN Fourth World Conference on Women. 1995. Beijing Declaration and Platform of Action. Available online: http:/ / www.un.org/womenwatch/daw / beijing/platform/ (accessed on 6 August 2018).

UN World Conference on Human Rights. 1993. Vienna Declaration and Programme of Action. A/CONF.157/23. Available online: http:/ / www.refworld.org/docid/3ae6b39ec.html (accessed on 4 August 2018).

UN Human Rights Committee. 2000. General Comment No. 28: Article 3 (The Equality of Rights between Men and Women) CCPR/C/21/Rev.1/Add.10. Geneva: UN Human Rights Committee.

UN Human Rights Committee. 2015. Draft General Comment 36 Article 6: Right to Life. Geneva: UN Human Rights Committee.

UN Human Rights Council. 2017. Second Report of the Special Rapporteur in the Field of Cultural Rights. A/HRC/34/56. Geneva: UN Human Rights Council.

UN Second Conference on Population. 1984. Recommendations for the Further Implementation of the World Population Plan of Action. Adopted in the World Population Conference. Mexico. 6 to 14 August 1984. Available online: http:/ / www.un.org/popin/icpd/conference/bkg/mexrecs.html (accessed on 4 August 2018).

UN International Conference on Population and Development. 1994a. Programme of Action of the International Conference on Population and Development. A/CONF.171/13. Available online: http://www.policyproject. com/matrix/Documents/Cairo.htm (accessed on 4 August 2018).

UN International Conference on Population and Development. 1994b. Statement of H.E. Archbishop Renato R. Martino (Holy See). Available online: http:/ / www.un.org/popin/icpd/conference/gov/940908193315.html (accessed on 23 December 2017).

UN International Conference on Population and Development. 1994c. Statement of Pope John Paul II (Holy See). Available online: http:/ / www.un.org/popin/icpd/prepcomm/govern/940423171030.html (accessed on 4 August 2018).

UN Population Fund (UNFPA). 2005. Rights into Action, UNFPA Implements Human Rights-Based Approach. New York: UNFPA.

UN Population Fund (UNFPA). 2010. A Human Rights-Based Approach to Programming. New York: UNFPA.

United National General Assembly. 2005. Integrated and Coordinated Implementation of and Follow-Up to the Outcomes of the Major United Nations Conferences and Summits in the Economic, Social and Related Fields; Follow-Up to the Outcome of the Millennium Summit. A/60/L.1. Available online: https:/ / documents-ddsny.un.org/doc/UNDOC/LTD/N05/511/30/PDF/N0551130.pdf?OpenElement (accessed on 27 July 2017).

United Nations Population Division. 1968. Resolution XVIII: Human Rights Aspects of Family Planning, Final Act of the International Conference on Human Rights A/CONF. 32/41. New York: United Nations Population Division. 
United Nations Population Division. 1974a. UN World Population Conference. 1974. World Population Plan of Action (WPPA). Bucharest. E/CONF, 60/L. 55. New York: United Nations Population Division.

United Nations Population Division. 1974b. UN World Population Conference. 1974. Working Group on the WPPA World Population Plan of Action. Draft Report of the Working Group E/CONF60/WG/L55. New York: United Nations Population Division.

United Nations Population Fund, Office of the United Nations High Commissioner for Human Rights, and Danish Institute for Human Rights. 2014. Reproductive Rights Are Human Rights: A Handbook for National Human Rights Institutions. New York: United Nations.

Van Eerdewijk, Anouka. 2001. How sexual and reproductive rights can divide and unite. European Journal of Women's Studies 8: 421-39. [CrossRef]

Yamin, Alicia Ely. 2013. From ideals to tools: Applying human rights to maternal health. PLoS Medicine 10: e1001546. [CrossRef] [PubMed]

Yamin, Alicia Ely, and Paola Bergallo. 2017. Narratives of Essentialism and Exceptionalism: The Challenges and Possibilities of Using Human Rights to Improve Access to Safe Abortion. Health and Human Rights 19: 1-11.

Yamin, Alicia Ely, and Vanessa M. Boulanger. 2013. Embedding sexual and reproductive health and rights in a transformational development framework: Lessons learned from the MDG targets and indicators. Reproductive Health Matters 21: 74-85. [CrossRef]

Zeidenstein, George. 2009. The Conundrum of Population and Reproductive Health Programs in the Early Twenty-First Century. In Reproductive Health and Human Rights: The Way Forward. Edited by Laura Reichenbach and Mindy Roseman. Philadelphia: University of Pennsylvania Press, pp. 40-50.

Zimmerman, Jonathan. 2015. Too Hot to Handle: A Global History of Sex Education. Princeton: Princeton University Press.

(C) 2018 by the author. Licensee MDPI, Basel, Switzerland. This article is an open access article distributed under the terms and conditions of the Creative Commons Attribution (CC BY) license (http:/ / creativecommons.org/licenses/by/4.0/). 